\title{
Radikalisme di Kalangan Terdidik
}

\author{
Nurlaila \\ IAIN Syaikh Abdurrahman Siddik Bangka Belitung, Indonesia \\ nurlailasupardi@gmail.com
}

\begin{abstract}
Abstrak:
Ada banyak faktor yang menyebabkan seseorang bisa bertindak radikal. Perubahan sosial politik dan keadaan ekonomi dianggap menjadi beberapa faktor mengapa seseorang menjadi radikal. Adapun agama dijadikan sebagai legitimasi untuk setiap aksi yang dilakukan. Saat ini, ideologi radikal telah merambah ke dunia pendidikan. Meskipun belum pada tahap yang mengkhawatirkan, namun berpotensi besar untuk merusak tatanan sosial yang sudah ada. Tulisan ini sedikit mengulas tentang perkembangan ideologi radikal, konsep jihad hingga tindakan terorisme di Indonesia beserta alternatif penanganannya pada kalangan terdidik. Adapun metode yang digunakan dalam penelitian ini adalah studi pustaka (library research).
\end{abstract}

Kata Kunci: Ideologi, Islam radikal, Kalangan terdidik

\begin{abstract}
:
There are many factors that cause a person to act radically. Socio-political changes and economic conditions are considered to be a number of factors why a person becomes radical. Religion is used as legitimacy for every action carried out. At present, radical ideology has penetrated the world of education. Although it is not yet at an alarming stage, it has great potential to damage existing social order. This paper briefly reviews the development of radical ideology, the concept of jihad and acts of terrorism in Indonesia along with alternative treatments for educated circles. The method used in this research is library research.
\end{abstract}

Keywords: Ideology, radical Islam, educated circles

\section{Pendahuluan}

Tidak ada agama yang mengajarkan kekerasan. Orang atau kelompok manusia yang melakukan kekerasan tidak lain disebabkan berbagai alasan yang kompleks. Seperti yang 
dikemukakan Amstrong bahwa pernyataan yang menyatakan agama adalah penyebab dari semua perang besar dalam sejarah adalah pernyataan yang tidak masuk akal dan ceroboh. Karena sejatinya perang dunia kesatu dan kedua bukan disebabkan agama, dan bukan juga untuk mencapai kepentingan dan tujuan agama. ${ }^{1}$

Dalam perkembangannya, agama muncul membawa kedamaian, menebar kasih sayang, dan menunjukkan jalan keselamatan. Semua agama mengajarkan pemeluknya untuk senantiasa melakukan kebaikan sehingga mendatangkan ketentraman untuk orang lain. Belum pernah ditemukan ada teks agama yang menyuruh untuk membunuh orang lain tanpa alasan yang dibenarkan.

Akan tetapi sejak peristiwa 11 September 2001 dan rentetan serangan teror setelahnya hingga peristiwa bom Surabaya medio Mei 2018, agama menjadi sorotan. Ada apa dengan Islam? Islam dituduh sebagai agama teroris. Islam dianggap sebagai biang teror yang terjadi di berbagai belahan dunia. Islam dianggap sebagai agama yang mengajarkan kekerasan. Bahkan tindakan terorisme yang dilakukan oleh orang Islam yang meskipun dilakukan bukan karena motivasi agama tetap dianggap sebagai bagian dari pengaruh ideologi Islam. ${ }^{2}$

Mengapa penganut gerakan Islam radikal yang kemudian bermetamorfosa menjadi teroris banyak bermunculan saat ini? Sang teroris pun bukan orang sembarangan. Banyak dari mereka memiliki latar belakang pendidikan. Tak ada rasa takut dalam diri mereka saat melakukan tindakan teror. Bahkan terkesan dari mereka menganggap bahwa tindakan mereka adalah gerakan jihad membela agama. Sehingga penghilangan nyawa orang lain menjadi sesuatu yang dibenarkan demi agama.

Lantas bagaimana meredam penyebaran ideologi Islam radikal yang sekarang banyak menyasar kaum terdidik? Jika lembaga pendidikan bahkan sudah terpapar ideologi radikal, apakah menunjukkan bahwa gerakan Islam radikal sudah sedemikian masif?

Tulisan ini sedikit mengulas tentang perkembangan ideologi radikal, konsep jihad hingga tindakan terorisme di Indonesia beserta alternatif penanganannya pada kalangan terdidik.

${ }^{1}$ Karen Amstrong dalam Azyumardi Azra, Transformasi Politik Islam Radikalisme, Khilafatisme, dan Demokrasi, ( Jakarta :Paranamedia Group, 2016), hal. 4. Karen Amstrong menurut Azra memiliki empati kuat pada agama. Termasuk Islam. Menurutnya jika ada yang berperang faktor utamanya adalah perebutan sumber daya alam yang semakin langka.

${ }^{2}$ Lihat Jeffrey M. Bale, "Denying the Link between Islamist Ideology and Jihadist Terrorism "Political Correctness"and the Undermining of Counterterrorism", pp. 5-27. Diakses pada 14 September 2018 dari https://about.jstor.org/terms//262970006 
Nurlaila

\section{Problem Ideologi Islam Radikal}

Radikalisme berasal dari kata radikal yang memiliki beberapa arti, yaitu (1) secara mendasar (sampai pada hal yang prinsip), (2) amat keras menuntut perubahan, 3) maju dalam berpikir atau bertindak. ${ }^{3}$ Radikalisme merupakan paham atau aliran yang berupaya melakukan perubahan atau pembaharuan sosial dan politik dengan cara kekerasan atau drastis. ${ }^{4}$

Radikalisme menurut Agus Surya Bakti dibagi ke dalam dua bentuk yaitu pemikiran dan tindakan. Dalam hal pemikiran, radikalisme adalah ide yang bersifat abstrak dan menghalalkan kekerasan untuk mencapai suatu tujuan. Adapun dalam bentuk tindakan, radikalisme berupa pada aksi yang dilakukan dengan cara kekerasan dan anarkis untuk mencapai tujuan. ${ }^{5}$ Dari pendapat ini radikalisme selama tidak beralih ke wilayah gerakan, maka tidak dianggap sebagai sesuatu yang berbahaya. Orang bisa saja berpikiran radikal, namun belum tentu suka melakukan aksi kekerasan untuk mencapai apa yang mereka inginkan.

Selanjutnya Zuly Qadir mengemukakan bahwa radikalisme juga juga bisa diartikan sebagai Islamisme. Islamisme adalah paham yang menyatakan bahwa agama sejatinya melingkupi seluruh dimensi pada masyarakat modern. Segala bidang kehidupan dalam masyarakat mulai dari pemerintah, pendidikan, sistem hukum, hingga kebudayaan dan ekonomi harus sesuai dengan hukum agama Islam. ${ }^{6}$

Adapun kelompok Islam radikal secara sederhana dapat dikatakan sebagai kelompok yang mempunyai keyakinan ideologis tinggi dan fanatik yang mereka perjuangkan untuk menggantikan tatanan nilai dan sistem yang sedang berlangsung. Dalam kegiatannya mereka seringkali menggunakan aksi-aksi yang keras, bahkan tidak menutup kemungkinan bertindak kasar terhadap aktivitas kelompok lain yang dinilai bertentangan dengan keyakinan mereka. Jamhari menyebutkan secara sosio-kultural dan sosio-religious, kelompok radikal ini mempunyai ikatan kelompok yang kuat dan menampilkan ciri-ciri penampilan diri dan ritual mereka yang khas. Kelompok 'Islam radikal' sering bergerak secara bergerilya, walaupun banyak juga yang bergerak secara terang-terangan. ${ }^{7}$

Radikalisme agama yang berujung pada gerakan menghalalkan kekerasan sebenarnya tidak hanya terjadi pada agama tertentu. Tapi juga pada agama lainnya. Pada dasarnya setiap tradisi agama-agama besar menyediakan tempat bernaung bagi pelaku-pelaku kekerasan.

${ }^{3}$ https://kbbi.we.id/radikal.html

4 https://kbbi.we.id/radikalisme.html

5 Agus Surya Bakti, Darurat Terorisme : Kebijakan Pencegahan, Perlindungan dan Deradikalisasi, (Jakarta: Daulat Press, 2014), hal. 155.

${ }^{6}$ Zuly Qadir, Radikalisme Agama di Indonesia, (Yogyakarta: Pustaka Pelajar, 2014), hal.26

${ }^{7}$ Jamhari dan Jajang Jahroni, Gerakan Salafi Radikal di Indonesia, (Jakarta : RajaGrafindo Persada, 2004), hal. 2-3 
Semua agama secara inheren bersifat revolusioner yang mampu menyediakan sumber-sumber ideologis untuk sebuah pandangan alternatif mengenai tatanan publik. ${ }^{8}$

Lantas jika agama berperan penting terhadap munculnya ideologi radikal berarti bertentangan dengan pandangan bahwa agama adalah sumber perdamaian. Agama berperan penting dalam perdamaian adalah hal yang tak terbantahkan. Namun dalam realitanya, agama memang tidak selalu dapat memainkan peran tersebut. Betapa kita melihat dari masa ke masa agama oleh kelompok yang memiliki agenda keagamaan dan politik tertentu menjadi alat untuk menyebar kebencian, konflik, kekerasan dan perang. Disatu sisi agama mengajarkan perdamaian, kerukunan dan hidup berdampingan dengan agama lain. Namun oleh sebagian kecil penganutnya agama ditampilkan dalam wajah yang menakutkan dan dijadikan sumber kekerasan dan pertikaian. ${ }^{9}$

Secara karakteristik Islam tidak mengajarkan sikap radikal apalagi menyuruh untuk berkonflik. Tidak ada dalam sejarah Rasulullah SAW memaksa orang Yahudi untuk masuk Islam. Bahkan karena kelemahlembutan sikap Rasulullah terhadap non muslim membuat banyak masyarakat di luar Islam yang akhirnya memilih untuk bersyahadat di depan Rasulullah.

Munculnya radikalisme di kalangan umat Islam sering dikaitkan dengan paham keagamaan yang sebetulnya tidak bisa dibenarkan juga. Banyak faktor yang bisa menyebabkan seseorang bisa bertindak radikal. ${ }^{10}$ Faktor-faktor tersebut antara lain politik, lingkungan, ekonomi bahkan pendidikan dapat mempengaruhi seseorang menjadi radikal. Namun demikian, orang bisa bertindak radikal bisa disebabkan oleh fanatisme keagamaan yang sempit,

\footnotetext{
${ }^{8}$ Mark Juergens Meyer dalam Tolhah Hasan, ” Islam dan Radikalisme Agama”, pp.1-6. Diakses pada 14 September 2018 dari lp3.um.ac.id/downlot.php?file=80_01. Tolhah menyebutkan bahwa radikalisme agama tidak terjadi dalam satu agama saja. Radikalisme agama juga terjadi pada :

1. Agama Yahudi di Palestina, seperti yang dilakukan oleh Zionisme Messianis yang anti perdamaian yang diupayakan oleh Yitzak Rabin, yang berakibat terbunuhnya PM Israil tersebut (1995), oleh Yigal Amir, juga teror di Hebron yang dilakukan oleh Baruch Goldstein.

2. Agama Katholik di Irlandia Utara (dikenal dengan Irish Republican Army / IRA).

3. Agama Protestan di Amerika Serikat, antara lain yang digerakkan oleh Timothy McVeigh dan Chistian Identity. 4. Agama kaum Sikh di India yang digerakkan oleh Jarnail Singh, yang korbannya antara lain PM Indira Gandi.

5. Agama Hindu-Budha di Jepang, yang digerakkan oleh Aum Shinrikyo, dengan aksinya menebar gas beracun di dalam kereta api bawah tanah di Tokyo.

6. Agama Islam, seperti gerakan Al-Qaidah yg dipimpin Usamah bin Laden di beberapa negara, atau Boko Haram di Nigeria, dan yang belakangan menghebohkan dunia yaitu ISIS yang dideklarasikan Abu Bakar at-Bagdadi di Irak Utara.

${ }^{9}$ Azyumardi Azra, Transformasi Politik Islam Radikalisme, Khilafatisme, dan Demokrasi, (Jakarta : Prenadamedia Group, 2016), hal.12

10 Wawan H. Purwanto, Terorisme Undercover: Memberantas Terorisme hingga ke Akar-akarnya, Memungkinkah? (Jakarta: CMB Press, 2007), hal.15
} 
Nurlaila

rasa tertekan, terjajah, tidak aman secara psikososial, serta ketidakadilan pada lingkup lokal maupun global. ${ }^{11}$

Islam sejatinya datang untuk menebar keselamatan untuk seluruh alam. Islam datang bukan untuk menebar permusuhan apalagi mengajarkan pembunuhan. Namun banyaknya tindakan-tindakan radikal yang dilakukan sekelompok umat Islam menghempas image Islam sebagai agama yang mengajarkan jalan keselamatan. Setiap hari para pemuka agama berupaya mengkampanyekan Islam sebagai ajaran yang mengajarkan kasih sayang namun saat itu juga ada oknum umat Islam yang dengan gagahnya membunuh orang lain atas dasar perintah agama.

Adalah hak setiap orang untuk memilih jalan hidupnya. Mau jadi kafir, fundamentalis, radikalis, atau bahkan ekslusif. Namun jika pilihan hidupnya itu mengancam keselamatan hidup orang lain maka hal tersebut tidak bisa dibenarkan. Perilaku kekerasan yang mengganggu tatanan kehidupan yang damai akan membentuk iklim komunikasi masyarakat yang saling curiga dan tidak aman. Oleh karena itu sangat beralasan jika pemerintah mengecam setiap tindakan kekerasan baik secara verbal maupun non verbal yang dilakukan oleh kelompok radikal karena jelas bertentangan dengan konstitusi kita yang menjamin keamanan dan kebebasan menjalankan ajaran agama. ${ }^{12}$

\section{Ciri Khas Kelompok Islam Radikal}

Jamhari dan Jajang Jahroni mengidentifikasi kelompok Islam radikal umumnya memiliki beberapa landasan ideologis. Pertama, kelompok ini berpendapat bahwa Islam merupakan pandangan hidup yang komprehensif dan bersifat total sehingga tidak bisa dipisahkan dari kehidupan politik, hukum dan masyarakat. Kedua, seringkali mereka menganggap bahwa masyarakat Barat berideologi sekuler dan cenderung materialistis sehingga harus ditolak. Ketiga, kelompok ini cenderung mengajak pengikutnya untuk kembali kepada Islam sebagai upaya merubah tatanan kehidupan sosial. Keempat, mereka menolak produk-produk hukum warisan kolonialisme dan harus menegakkan hukum Islam sebagai satusatunya sumber hukum yang diterima. Kelima, kelompok ini tidak menolak modernisasi, terbukti mereka banyak menggunakan alat-alat komunikasi modern handphone, internet, media sosial dalam mendukung keberhasilan aksi mereka. Keenam, kelompok ini berkeyakinan

${ }^{11}$ Mark Jurgensmeyer, Terorisme Para Pembela Agama (Yogyakarta: Terawang Press, 2003), hal.16

${ }^{12}$ R. Hrair Dikmejian dalam Sahri, "Radikalisme Islam di Perguruan Tinggi Perspektif Politik Islam”, pp. 238-268 diakses 14 September 2018 dari jurnal Al Daulah Nomor 6 Vol. 1 tahun 2016 
bahwa usaha-usaha Islamisasi pada masyarakat Muslim tidak akan berhasil tanpa organisasi atapun pemebntukan sebuah kelompok yang kuat. ${ }^{13}$

Sementara itu juga terdapat beberapa karakteristik mengapa sebuah kelompok pantas disebut sebagai "Islam radikal". Pertama, mereka sering menunjukkan mentalitas 'Perang Salib'. Kedua, penegakan hukum Islam secara keras, bahkan cenderung dipaksakan. Ketiga, kelompok ini cenderung untuk melawan pemerintah beserta sistem-sistem yang ada didalamnya yang dianggap tidak sah, khususnya karena kurangnya perhatian terhadap masalah 'patologi sosial' masyarakat yang mereka labeli sebagai maksiat dan kemungkaran. Keempat, Jihad sebagai jalan untuk menegakkan agama mendapat tempat terhormat. Jihad dalam kelompok ini memiliki kesan kuat sebagai usaha fisik untuk memerangi musuh-musuh Islam. Kelima, setelah melihat buruknya hubungan Islam dan Yahudi di Palestina, ditambah dengan isu klasik Kristenisasi, kelompok Islam radikal menganggap bahwa kaum Yahudi dan Kristen tidak lagi sebagai 'Ahli Kitab' melainkan kaum kafir dan memiliki tujuan yang sama untuk berkonspirasi melawan Islam dan dunia Islam. ${ }^{14}$

Sofyan Tsauri menyebutkan bahwa para pengikut gerakan Islam radikal pada umumnya adalah mereka yang merasa tertindas, teraniaya dan kemudian berupaya melakukan perubahan untuk menciptakan kondisi sosial politik yang lebih baik. ${ }^{15}$ Islam pada dasarnya mengajarkan kepada umatnya untuk membantu dan mengasihi pihak-pihak yang lemah dan teraniaya sebagaimana tercantum dalam Alquran maupun hadits. Nabi Muhammad adalah suri tauladan terbaik dalam membantu kaum-kaum yang teraniaya, sebagai contoh membela kaum wanita yang begitu teraniaya dalam sistem sosial Arab sebelum Islam, atau membebaskan budakbudak yang disiksa oleh pemilik mereka.

Namun yang harus dipahami adalah dalam Islam bantuan kepada mereka yang tertindas bukan tanpa persyaratan maupun konteks tertentu. Yang pertama yang harus dikaji adalah faktor maupun latar belakang apakah yang menyebabkan mereka menjadi terkesan seperti teraniaya, apakah karena tindakan mereka sendiri yang mengganggu ketentraman masyarakat dan bertentangan dengan ajaran Islam? Jika hal tersebut faktornya, maka individu atau kelompok tersebut tidak berhak untuk dibela, bahkan harus ditentang apabila langkah persuasif

\footnotetext{
${ }^{13}$ Jamhari dan Jajang Jahroni, Gerakan Salafi Radikal di Indonesia, (Jakarta : RajaGrafindo Persada, 2004), hal. 4-6

${ }_{14}$ Jamhari dan Jajang Jahroni, Gerakan Salafi Radikal di Indonesia, Jakarta : RajaGrafindo Persada, 2004), hal. 6-8

${ }^{15}$ Seperti yang diungkapkan Sofyan Tsauri (mantan anggota Al Qaeda di Indonesia) bahwa radikalisme dipicu adanya ketidakadilan kepada umat Islam, konflik sosial, kesenjangan sosial dan kekecewaan kepada pemerintah. Lihat "Memutus Rantai Ideologi Radikal dan Terorisme di dalam Penjara", Merdeka.com, 4 Juni 2017, Diakses 25 September 2018
} 
Nurlaila

sudah dilakukan untuk menyadarkan mereka menemui jalan buntu. Dalam istilah politik Islam kelompok atau individu seperti ini dinamakan sebagai "bughat" yaitu pembangkang" yang melakukan kekacauan, gangguan, maupun tindakan anarkis dalam masyarakat. ${ }^{16}$

Upaya perubahan yang dilakukan oleh kaum Islam radikal meskipun didorong oleh motif yang baik seperti mendorong terciptanya kondisi sosial yang lebih baik tetap saja tidak bisa diterima jika harus menimbulkan korban. Perubahan memang meniscayakan sosial cost, tetapi biaya yang terlalu besar juga harus dihindari. Dalam Islam jelas segala hal yang bertujuan baik hendaknya dilakukan dengan metode yang baik pula. Dan perubahan radikal yang dilakukan oleh gerakan Islam garis keras terbukti banyak memakan korban terutama rakyat sipil yang tidak bersalah.

Selanjutnya lebih jauh, perubahan radikal yang dilakukan oleh kelompok radikal sangat mungkin didorong oleh pemahaman sendiri bahwa perubahan secara damai tidak dimungkinkan lagi karena adanya sistem yang sudah mapan. Maka jalan kekerasan dianggap cara yang paling ampuh untuk mengubah situasi menjadi seperti yang diharapkan. Jalan kekerasan yang ditempuh ini adalah cermin keputusasaan yang tidak percaya akan ketetapan Tuhan. Sudah selayaknya kita harus yakin bahwa Tuhan akan menolong siapa saja yang berniat baik, ikhlas, serta melaksanakan niat yang baik tersebut dengan cara yang baik pula.

Kasus seperti ini harus dipahami dengan sebaik-baiknya, agar kita dapat melihat duduk masalah sesuai dengan porsinya. Dengan demikian tidak menimbulkan distorsi maupun citra yang buruk terhadap Islam, bahwa Islam tidak memperhatikan pihak-pihak yang oleh sebagian orang dianggap sebagai orang yang "teraniaya".

\section{Gerakan Islam Radikal di Indonesia}

Gerakan Islam radikal telah muncul di Indonesia pada masa kemerdekaan Indonesia. Gerakan Islam garis kelas ini dapat dikatakan sebagai akar Islam garis keras di era reformasi. Gerakan tersebut adalah Darul Islam / Tentara Islam Indonesia) atau disingkat DI/TII dan Negara Islam Indonesia(NII) yang muncul tahun 1950-an. Gerakan ini mempunya visi dan misi menjadikan syariat Islam sebagai dasar negara Indonesia. Awalnya gerakan ini muncul di Jawa Barat, Aceh dan Makassar. Gerakan ini berhenti paada awal 1960-an karena semua pimpinannya terbunuh. Meskipun demikian, gerakan ini sebenarnya tidak benar-benar hilang.

${ }^{16}$ Azyumardi Azra, Konflik Baru Antar Peradaban Globalisasi, Radikalisme dan Pluralitas, (Jakarta: Rajagrafindo Persada, 2002), hal. 91-92 
Gerakan ini kembali muncul dengan format baru di awal 1970 dan 1980 dengan nama Komando Jihad, Ali Imron, dan sebagainya dengan maksud untuk mendirikan Negara Islam. ${ }^{17}$

Gerakan Islam radikal ${ }^{18}$ ini awal mulanya muncul sebagai bentuk perlawanan terhadap komunisme. Selain itu juga kelompok ini merupakan kelompok penentang Pancasila. Bagi mereka sistem demokrasi Pancasila itu haram hukumnya dan pemerintah yang menjalankannya dianggap sebagai taghut atau setan Begitupun terhadap masyarakat yang mendukung demokrasi Pancasila juga mereka anggap sebagai setan. Kelompok ini berusaha keras untuk menerapkan hukum syariah sebagai solusi kehidupan bernegara. ${ }^{19}$

Sebenarnya alasan utama gerakan Islam garis keras melawan pemerintah dengan kekerasan dilatarbelakangi oleh ketidakpuasan politik, keterpinggiran politik dan sebagainya. Bukan karena agama. Namun agama dijadikan sebagai faktor legitimasi maupun perekat ukhuwah yang sangat penting bagi keberlangsungan gerakan ini. Meskipun demikian, tindakan yang dilakukan oleh kelompok ini tidak bisa dijadikan alasan menuduh Islam sebagai biang radikalisme.

\section{Penyebab Islam Radikal Berkembang di Indonesia}

Menurut Azra sebagaimana dikutip Abdul Munip, seseorang yang terpapar ideologi radikal bisa dikarenakan beberapa faktor. Pertama, pemahaman keagamaan yang tekstual dan sepotong-potong terhadap ayat Al Quran. Kedua, bacaan yang salah terhadap sejarah umat Islam ditambah dengan idealisasi berlebihan terhadap umat Islam pada masa tertentu. Ini terlihat dalam pandangan dan gerakan salafi, khususnya dalam spektrum sangat radikal seperti wahabiyah yang muncul di semenanjung Arabia pada akhir abad ke 18 awal sampai pada abad 19 dan terus merebak sampai sekarang. Tema pokok dan sel salafi ini adalah pemurnian Islam, yakni membersihkan Islam dari pemahaman dan praktek keagamaan yang mereka pandang sebagai bid'ah, yang tidak jarang dilakukan dengan cara kekerasan. Ketiga, deprivasi politik, sosial dan ekonomi yang masih bertahan dalam masyarakat. Pada saat yang bersamaan, disorientasi dan dislokasi sosial budaya dan ekses globalisasi, dan semacamnya sekaligus

\footnotetext{
${ }^{17}$ Jamhari dan Jajang Jahroni, Gerakan Salafi Radikal di Indonesia, (Jakarta : RajaGrafindo Persada, 2004), hal.17-18

${ }^{18}$ Ada 3 kelompok kekuatan yang mendukung pelaksanaan hukum syariah: Salafi-Wahabi, Ikhwanul Muslimin, dan Hizbut Tahrir yang mempengaruhi mahasiswa-mahasiswa dari berbagai belahan dunia yang belajar di Timur Tengah, khususnya Mesir, Saudi Arabia dan Syiria. Bedanya, kalau Salafi-Wahaby cenderung ke masalah ibadah formal yang berusaha "meluruskan" orang Islam. Ikhwan bergerak lewat gerakan usroh yang beranggotakan 7-10 orang dengan satu amir. Mereka hidup sebagaimana layaknya keluarga di mana amir bertanggungjawab terhadap kebutuhan anggota usrohnya. Kelompok ini menamakan diri kelompok Tarbiyah yang merupakan cikal bakal PKS.

19 Sa'dullah Affandy, Akar Sejarah dan Pola Radikalisme di Indonesia, 8 Juli 2016, www. nu.or.id diakses 23 September 2018
} 
Nurlaila

merupakan tambahan faktor-faktor penting bagi kemunculan kelompok-kelompok radikal. Kelompok-kelompok sempalan tersebut tidak jarang mengambil bentuk kultus (cult) yang sangat eksklusif, tertutup, dan berpusat pada seseorang yang dipandang kharismatik. Keempat, masih berlanjutnya konflik sosial bernuansa intra dan antar agama dalam masa reformasi. Lebih spesifik hal tersebut disebabkan karena: pertama, euphoria kebebasan sehingga tidak peduli dengan pihak-pihak lain sehingga menurunkan toleransi. Kedua, masih berlanjutnya fragmentasi politik dan sosial khususnya di kalangan elite politik, sosial, milier, yang terus mengimbas ke lapisan bawah dan menimbulkan konflik horizontal yang laten dan luas. ${ }^{20}$

Sementara menurut Adriana Elizabeth, Kepala Pusat Penelitian Politik LIPI, mengungkapkan ada empat alasan mengapa radikalisme berkembang pesat di Indonesia, antara lain: ${ }^{21}$

1. Kepentingan personal

Hal ini terutama menyangkut ideologi dan finansial. Banyak para pengikut Islam radikal berawal dari kegelisahan akan ideologi hidup mereka. Saat mereka merasa tak nyaman dengan sistem demokrasi mereka beralih ke ideologi yang lain, salah satunya radikalisme. Selanjutnya, betapa banyak orang yang berhasil terbuai untuk hijrah ke Suriah karena terbuai fasilitas harta dan bidadari-bidadari cantik yang dijanjikan ISIS.

2. Propaganda politik

Propaganda politik yang disebar lewat media sosial berhasil menarik para pencari identitas untuk ikut masuk dalam gerakan radikal.

3. Pemahaman soal penyucian diri

Para pengikut gerakan ini didoktrin bahwa dunia sudah menjelang akhir zaman dan kiamat, dan sudah waktunya untuk bertaubat dengan dibimbing oleh pemimpin gerakan ini.

4. Etika elit politik yang buruk

Hal terkait dengan pelaksanaan demokrasi yang merupakan perwujudan nilai-nilai Pancasila. Permasalahan demokrasi yang carut marut oleh para elit politik menyebabkan beberapa kalangan memilih ideologi radikal.

\section{Global Jihad}

${ }^{20}$ Abdul Munip, "Menangkal Radikalisme di Sekolah. " Jurnal Pendidikan Islam Volume I Nomor 2 (2012), hal.159-181

${ }^{21}$ Riani Sanusi Putri, "LIPI Ungkap 4 Alasan Mengapa Radikalisme Berkembang di Indonesia", Tempo.co, 20 Februari 2018 dari https://nasional.tempo.co/read/1062388 
Jihad adalah hal yang tiada habisnya dibicarakan sejak masa awal Islam hingga modern-kontemporer. Banyak para pemuka agama maupun pemikir Muslim yang terlibat dalam pembicaraan tentang jihad, baik dalam kaitan dengan doktrin fikih maupun dengan konsep politik Islam. Teori tentang jihad yang mereka kemukakan sedikit mengalami pergeseran sesuai dengan konteks dan lingkungan masing-masing.

Istilah jihad paling sering disalahartikan oleh banyak pihak. Kesalahpahaman ini tidak hanya terjadi di kalangan Muslim saja tapi juga oleh masyarakat Barat. Saat kata jihad disebut, makna yang muncul adalah individu atau kelompok Muslim yang menyerbu ke berbagai wilayah di Timur Tengah atau tempat-tempat lain di Amerika, Eropa, Afrika, Asia Selatan, dan Asia Tenggara, negatif sejak peristiwa WTC 11 September 2001 hingga masa kini. ${ }^{22}$

Jihad oleh banyak pihak sering diterjemahkan sebagai perang suci. ${ }^{23}$ Perang suci ini dalam pemahaman Kristen Eropa adalah perang melawan orang kafir. Jihad ini tidak dianggap sebagai cara memaksa orang kafir untuk memeluk Islam, namun tujuan pokoknya adalah ekspansi wilayah dan pembelaan wilayah Islam dari serangan kaum kafir. Namun istilah perang suci ini kemudian tidak berarti sebagai perang yang dilakukan dengan motif agama. Dengan demikian jihad tidak sama dengan perang suci. Secara historis, jihad pada umumnya dilakukan atas dasar politik, seperti perluasan wilayah Islam atau pembelaan diri kaum Muslimin terhadap serangan luar.

Masa periode Makkah, jihad dilakukan secara halus. Nabi Muhammad SAW cukup memperingatkan masyarakat Mekkah tentang kekeliruan menyembah berhala dan menyeru untuk menyembah Allah. Dalam Alquran surah Al Ankabut ayat 6 dikatakan bahwa jihad merupakan cara untuk memperoleh keselamatan diri daripada penyebaran agama. Namun sebaliknya di surah yang lain yaitu At Taubah ayat 41; Al Hujurat ayat 15; As Shaf ayat 11; At Tahrim ayat 9, jihad digambarkan dengan “mengerahkan segenap upaya”. Namun, juga tidak

\footnotetext{
${ }^{22}$ Apapun fakta dan argumen yang bertujuan membantah citra negatif tersebut menjadi sulit diterima. Apalagi setelah munculnya Islamic State Irak and Syuriah atau ISIS, dan rentetan bom bunuh diri di berbagai negara yang banyak dilakukan segelintir umat Islam membuat citra Islam dan muslim semakin memburuk. Semakin sering seruan membantah jihad kekerasan dan bom bunuh diri adalah ajaran Islam, pada saat yang sama tetap saja ada individu dan kelompok Muslim yang melakukan kekerasan dan bom bunuh diri dengan menyalahgunakan konsep dan praktek jihad.

${ }_{23}$ Peperangan yang disetujui dalam agama. Beberapa sarjana Muslim modern mengklaim bahwa tujuan jihad sejati adalah untuk "membangun tatanan sosial yang adil"; yang lainnya menambahkan bahwa cara untuk mewujudkan tujuan ini adalah melalui perjuangan kekerasan. Pemikir muslim membagi jihad menjadi "perjuangan dengan hati dan jiwa" (melawan kejahatan), "berjuang dengan lidah dan pena "(menyebarkan katakata Islam)," berjuang dengan tangan "(aksi politik atau protes), dan" berjuang dengan pedang "(pertempuran bersenjata). Namun makna dominan "jihad" dalam budaya Muslim Sunni tetap "Peperangan Islami, "yang mengacu pada perang, lebih spesifik untuk bertarung dengan niat membunuh (qital). Lihat Philipp Holtmann, “ 'Terrorism and Jihad Differences and Similarities' Perspectives on Terrorism," Vol. 8, No. 3 (June 2014), pp. 140-143. Diakses 24 September 2018 dari https://www.jstor.org/stable/26297185
} 
Nurlaila

bisa dibantah, dalam ayat tertentu istilah jihad sama artinya dengan "perang" (al harb) dan "pertempuran" (al qatl). Oleh sebab itu, jumhur ulama berpendapat bahwa kewajiban jihad dapat dilaksanakan dalam empat bentuk, yaitu dengan hati, dengan lidah, dengan tangan, dan dengan pedang. Jihad bentuk pertama berkaitan dengan perlawanan terhadap iblis dan rayuannya kepada manusia untuk melakukan kejahatan; jihad internal, jihad melawan hawa nafsu dipandang sangat penting, sehingga disebut jihad akbar. Jihad jenis kedua dan ketiga dijalankan terutama untuk menegakkan kebenaran dan mencegah kemungkaran. Jihad jenis keempat sama artinya dengan perang dan berkenaan dengan pertempuran melawan orang kafir dan musuh Islam. ${ }^{24}$

Jihad dalam pengertian perang merupakan tindakan pembelaan diri bukan agresi atau serangan. Namun banyak pihak yang salah paham terhadap konsep jihad ini. Sebagaimana yang dilakukan oleh para pengikut Islam garis keras seperti Al Qaeda maupun Jamaah Islamiyah. ${ }^{25}$ Tindakan serangan membabi buta maupun bom bunuh diri yang mereka anggap jihad banyak membunuh orang-orang yang tak bersalah. Jihad sejatinya dilakukan bukan untuk menimbulkan keresahan namun membuat keadaan menjadi lebih baik tanpa harus membuat kekacauan. Adapun kekerasan yang dilakukan oleh kaum Islam radikal dengan mengatasnamakan jihad adalah tak lebih dari upaya legitimasi atau pengesahan yang justru menjatuhkan makna jihad itu sendiri.

\section{Terorisme Keagamaan : Perusak Citra Agama}

Terorisme adalah suatu istilah yang mengandung kekaburan dan sering disalahtafsirkan. Apalagi, istilah terorisme dihubungkan dengan ideologi politik tertentu. Upaya untuk mendefinisikan istilah terorisme biasanya didasarkan atas asumsi, bahwa setiap tindakan kekerasan, terutama kekerasan politik (political violence) adalah justifiable sementara kekerasan dalam bentuk lain adalah unjustifiable. Kekerasan bentuk kedua ini yang tergolong teror. ${ }^{26}$ Hingga saat ini sebenarnya sulit untuk mengartikan arti dari terorisme. Jika ada terorisme keagamaan, maka sejatinya itu mengatasnamakan agama. Karena semua agama tidak membenarkan tindakan teror yang mengancam kehidupan orang lain dalam bentuk apapun

${ }^{24}$ Azyumardi Azra, Transformasi Politik Islam Radikalisme,Khilafatisme, dan Demokrasi, (Jakarta : Prenadamedia Group, 2016) hal.139

${ }^{25}$ Lihat Ganesan Annamalai, The Impact of Osama Bin Laden's death on the Landscape of Global Jihad : : Counter Terrorist Trends and Analyses, Vol. 3, No. 8 (August 2011), pp. 10-13. Diakses 24 September 2018 dari https://www.jstor.org/stable/26350999

26 Azyumardi Azra, Pergolakan Politik Islam: Dari Fundamentalisme, Modernisme Hingga PostModernisme (Jakarta: Paramadina, 1996), hal. 143. 
dan untuk tujuan apapun. Orang atau kelompok manusia yang melakukan kekerasan tidak lain disebabkan berbagai alasan yang kompleks.

Terorisme yang menghalalkan kekerasan seluruhnya berlawanan dengan kemanusiaan dalam Islam. ${ }^{27}$ Islam mengajarkan etos kemanusiaan yang sangat menekankan kemanusiaan universal. Islam menganjurkan umat-Nya untuk berjuang mewujudkan perdamaian, keadilan dan kehormatan. Namun perjuangan itu tidaklah harus dilakukan dengan kekerasan apalagi lewat jalan terorisme. Setiap perjuangan untuk keadilan apapun itu, haruslah dimulai dengan konsep awal bahwa keadilan adalah hal universal yang mau tidak mau harus dibela dan diperjuangkan oleh manusia manapun.

Islam menganjurkan dan memberikan pembenaran kepada setiap Muslim untuk berjuang, membela hak-haknya, serta menggunakan kekerasan untuk menghadapi kaum penindas, musuh-musuh Islam dan pihak luar yang menunjukkan sikap bermusuhan dan tidak mau hidup berdamai dengan Islam dan kaum Muslimin. ${ }^{28}$

Akan tetapi, meskipun Islam membenarkan penganutnya untuk berjuang membela hakhaknya namun Islam juga mewajibkan umatnya menegakkan kebaikan dan melawan keburukan atau amar ma'ruf nahi munkar. Ada banyak cara dalam melakukan kewajiban amar ma'ruf nahi munkar tersebut. Namun yang jelas menurut ajaran Islam, bahwa penggunaan kekerasan apalagi teror merupakan tindakan kriminal dan tidak bisa dibenarkan. Jika kekerasan dan terror dilakukan untuk menumpas keburukan maka itu sama saja dengan menumpas keburukan dengan keburukan. Lantas apa bedanya kita dengan pelaku keburukan itu sendiri?

Ada banyak ayat Al Quran yang menjelaskan tentang individu maupun kelompok yang ditindas oleh masyarakat maupun penguasa. ${ }^{29}$ Sebagai jawaban atas situasi yang dialami tersebut, orang-orang beriman dianjurkan untuk tetap mempertahankan keimanan mereka dan agar selalu berada dalam jalan yang benar, dan bersabar dalam menghadapi penindasan, ketidakadilan dan kekerasan yang mereka derita. Dalam persoalan seperti ini, Alquran tidak

${ }^{27}$ Para teroris memanipulasi teologi Islam dengan menganggap sesama muslim dan di luar muslim sebagai kafir dan ahli bid'ah, thaghut (pelanggar), murtad. Mereka menganggap mereka mendapat mandat dari Tuhan untuk melakukan tindakan yang secara moral dilarang dalam agama. Lihat Syed Huzaifah Bin Othman Alkaff, "Using Theology to Legitimise Jihadist Radicalism": Counter Terrorist Trends and Analyses, Vol. 10, No. 3 (March 2018), pp.6-7. Diakses pada 15 September 2018 dari https://www.jstor.org/stable/26380429

${ }^{28}$ Lihat QS. Al Baqarah ayat 190-191, 216-217,;Al Anfal ayat 59-60; At Taubah ayat 36 ; Al Hajj ayat 39-40;Al Ahzab ayat 60-62; Al Hujurat 9-10. Dalam ayat-ayat Al Quran ini mengacu pada kelompok, bukan individu. Orang-orang Muslim dilihat sebagai satu kesatuan kelompok, bukan orang per orang. Begitupun musuhmusuh Islam disebut sebagai kelompok bukan individu. Jadi, dalam kacamata Islam, perilaku kekerasan terhadap individu merupakan perilaku kekerasan yang tidak sah dan tidak bermoral. Termasuk juga dalam hal ini adalah sweeping yang dilakukan terhadap individu yang diasumsikan sebagai representasi musuh-musuh kalangan Muslim.

${ }^{29}$ Lihat QS. Al A'raf ayat 123-126; Yunus ayat 108-109; Ibrahim ayat 12; dan Al Ahqof ayat 35. 
menyarankan penggunaan kekerasan untuk melakukan pembalasan terhadap penindasan tersebut. Bahkan Alquran senantiasa menganjurkan usaha-usaha perdamaian sedapat dan semaksimal mungkin sebelum melakukan tindakan pembelaan diri yang terpaksa harus menggunakan jalan kekerasan.

Akan tetapi ketika ayat-ayat yang berbicara tentang orang-orang yang tertindas maupun yang terusir dari tanah air mereka penting untuk dipahami bahwa Alquran sejatinya menganjurkan mereka yang tertindas dan terusir dari negeri mereka dengan mengorganisasi diri, menyusun strategi membela diri guna memperoleh kebebasan dari segala bentuk penindasan dan untuk memperoleh kehormatan diri dan agama. Ada dua aspek dalam ayatayat tersebut yaitu aspek internal dan eksternal. Secara internal Alquran menganjurkan agar mereka yang tertindas untuk tetap sabar sambil terus berjuang mempertahankan iman dan eksistensi mereka. Secara eksternal, perjuangan untuk membela dan mempertahankan diri dari serangan kelompok luar pada dasarnya adalah perjuangan untuk keadilan dan perdamaian.

Terorisme yang didefinisikan oleh Barat sering diistilahkan dengan kata jihad. Padahal jihad dan terorisme jelas dua kata yang berbeda. Mereka yang beranggapan bahwa tindakan terorisme adalah jihad jelas salah paham akan konteks jihad yang sebenarnya. Lebih pas memang jika terorisme dikatakan sebagai kekerasan politik. Meskipun kenyataannya, ada individu atau kelompok yang melakukan kekerasan dengan membawa pembenaran moral. Seperti yang dilakukan oleh para pejuang di Palestina terhadap Zionis Israel yang dibela Amerika Serikat dan beberapa negara Barat lainnya. Tindakan pembelaan dengan jalur kekerasan berdalih untuk membela diri dari penindasan yang dilakukan oleh Israel, merebut kembali tanah air mereka dan memperoleh keadilan dan perdamaian. Namun juga sulit ditolak, bahwa terdapat juga orang-orang dan kelompok pejuang Palestina yang tidak memiliki pembenaran secara moral untuk melakukan tindakan kekerasan, turut menyerang WTC dan orang-orang sipil yang tidak memiliki kaitan apa-apa dengan ketidakadilan dan penindasan. ${ }^{30}$ Sama seperti yang dilakukan pelaku bom Surabaya, bom Thamrin dan bom bunuh diri lainnya yang banyak memakan korban dari orang-orang yang tidak berdosa.

Walaupun ada semacam pembenaran moral dalam perjuangan rakyat Palestina, para pejuang Palestina selayaknya tetap melakukan upaya damai untuk melawan penindasan dan mendapatkan keadilan. Upaya perdamaian ini sangat penting, karena tindakan kekerasan yang dilakukan oleh para pejuang militan Palestina walaupun dengan dalih untuk membela diri dan

${ }^{30}$ Azyumardi Azra, Konflik Baru Antar Peradaban Globalisasi, Radikalisme dan Pluralitas, (Jakarta: Rajagrafindo Persada, 2002), hal. 82-83 
tanah air dari penindasan, telah dianggap sebagai tindakan terorisme. Para pejuang Palestina dianggap sebagai Teroris Muslim. Lebih parah lagi Terorisme Islam. Islam sebagai agama yang damai atau agama yang membawa perdamaian bagi pemeluk agama lain dianggap sebagai agama kaum teroris. Islam dirusak citranya oleh oknum umat Islam sendiri.

\section{Jaringan Teroris di Indonesia}

Peristiwa Bom Bali I dan II, bom Marriot, bom mapolresta Cirebon, bom Samarinda, Bom Sarinah, yang masih segar dalam ingatan kita pertengahan tahun 2018 satu keluarga jadi pelaku bom bunuh diri di Surabaya, bom Pasuruan, penemuan rakitan bom di Universitas Riau, dan berapa banyak berita penangkapan terduga teroris yang berseliweran di surat kabar, media televisi maupun media sosial lainnya, menunjukkan bahwa jaringan teroris di negeri ini sudah menunjukkan eksistensinya tanpa malu-malu lagi. ${ }^{31}$

Meskipun negeri menjunjung tinggi kebebasan beragama yang dilindungi oleh Undang-Undang, perkembangan jaringan teroris ternyata sudah pada tahap mengkhawatirkan. Jaringan teroris banyak menyasar masjid, aktivis dakwah kampus, maupun mereka yang sedang mencari identitas bahkan napi dalam penjara sekalipun.

Metamorfosis dari jaringan teroris Indonesia berawal dari kelompok Darul Islam atau Negara Islam Indonesia. ${ }^{32}$ Kelompok Darul Islam kemudian terpecah dan berdirilah kelompok Jamaah Islamiyah atau JI pada 1 Januari 1993. Kelompok ini kemudian berkembang dan berganti sebutan menjadi kelompok Majelis Mujahidin Indonesia pada 5 Agustus 2000. Selanjutnya pada September 2008, kelompok Majelis Mujahidin Indonesia atau MMI berkembang dan dikenal dengan sebutan kelompok Jamaah Ansharut Tauhid. Sementara kelompok NII dalam perkembangannya eksis dengan sebutan kelompok Mujahidin Indonesia Barat (MIB). Dari JAT dan MIB, kemudian berkembang jaringan-jaringan teroris Jamaah

${ }^{31}$ Kapolda Bali Petrus R. Golose mengulas soal aksi teror dalam tiga tahun terakhir. Tercatat ada 19 kali serangan dari kelompok terorisme dan orang yang terpapar radikalisme atau yang disebut lonewolf dan leaderless jihad dalam kurun itu. Serangan terbanyak terjadi di 2016. Di antaranya Bom Thamrin pada Januari, Bom Polres Surakarta pada Juli, Bom Gereja Santo Yosef pada Agustus, Serangan INP pada September, Bom Gereja Oikumene pada Oktober, rencana serangan teror kantor Polres Tangerang Selatan dan kantor Polsek Senen pada Desember. Belakangan, imbuh Petrus, teroris menjadikan anggota Polri sebagai target serangan mereka. 2015, sebanyak dua polisi terluka. 2016, satu orang meninggal dan 9 luka-luka. 2017, tiga orang meninggal dan 14 orang terluka. 2018 tiga polisi terluka. Lihat https://news.detik.com, 20 Februari 2018, diakses 26 September 2018

${ }^{32}$ Lihat Paul J. Carnegie, "Countering the (Re-) Production of Militancy in Indonesia between Coercion and Persuasion" : Perspectives on Terrorism, Vol. 9, No. 5 (October 2015), pp. 15-26 Diakses pada 14 September 2018 dari https://www.jstor.org/stable/26297431 
Nurlaila

Anshorut Syariah (JAS), Mujahidin Indonesia Timur (MIT), Jamaah Ansharut Daulah (JAD), dan Jamaah Ansharut Khilafah (JAK). ${ }^{33}$

\section{Radikalisme Kaum Terdidik}

Peristiwa bom Surabaya dan penemuan bom rakitan di Universitas Riau belum lama ini, menuai anggapan bahwa radikalisme sudah merambah ke dunia intelektual. Hal ini dikarenakan sang pelaku adalah alumni perguruan tinggi. Ditambah lagi dengan hasil temuan BNPT $^{34}$ yang menyebutkan bahwa 7 perguruan tinggi di Indonesia terpapar ideologi radikal.

Tahun 2017 PPIM UIN Jakarta melakukan survei nasional tentang opini dan aksi intoleran serta radikal. Dengan mengambil sampel 1522 siswa dan 337 baik yang berada dibawah Kemenag maupun yang berada di bawah Kemenristek Dikti di 34 provinsi dan berusia 16-22 diperoleh hasil dalam tataran opini 51,5 \% siswa dan mahasiswa intoleran, sementara 58,5 \% siswa dan mahasiswa radikal. Sementara untuk tataran aksi, 33\% siswa dan mahasiswa setuju bahwa jihad adalah perang, 23,35 \% setuju bahwa bom bunuh diri adalah jihad, dan $33,34 \%$ setuju perbuatan intoleran tidak bermasalah. ${ }^{35}$

Tahun 2018 PPIM UIN Jakarta juga melakukan penelitian terhadap guru agama tentang pandangan mereka mengenai agama dengan politik dan negara Indonesia. Penelitian dilakukan terhadap guru di 11 kota/ kabupaten di lima provinsi di Indonesia. Hasiln ya $82 \%$ guru setuju Pancasila dan UUD 1945 sesuai dengan syariah Islam dan oleh sebab itu tidak perlu diubah lagi. Sementara $18 \%$ guru agama menolak Pancasila, NKRI, UUD 1945, dan Bhinneka Tunggal Ika. Menarik kiranya untuk diketahui bahwa dalam $82 \%$ tersebut, $23 \%$ guru agama mendukung ormas yang memperjuangkan penegakan syariah Islam secara menyeluruh oleh negara. Mereka sangat setuju dengan konsep khilafah--konsep yang diusung oleh HTI yang sudah dibubarkan pemerintah. ${ }^{36}$

Dua hasil penelitian ini menunjukkan bahwa radikalisme sudah merambah ke dunia pendidikan. Pendidikan yang sejatinya membentuk siswa yang beriman, berakhlak mulia dan cinta tanah air ternyata berpotensi membentuk jiwa pemberontak. Hasil penelitian pertama

${ }^{33}$ Seperti disampaikan Kapolda Bali Irjen Petrus R. Golose dalam seminar Ilmiah "Cara Menangani Terorisme” di STIK/PTIK, lihat https://news.detik.com, 20 Februari 2018, diakses 26 September 2018

${ }^{34}$ Kebenaran temuan ini masih diperdebatkan. Namun banyak pihak menyetujui bahwa setelah peristiwa bom Surabaya dan penemuan bom rakitan di Universitas Riau yang pelakunya adalah alumni perguruan tinggi membuktikan bahwa kampus juga menjadi sasaran penyebaran paham radikal.

${ }^{35}$ Lihat video program “Satu Meja” Kompas TV, ‘ Radikalisme Mencengkeram Kampus?', 4 Juni 2018

36 Azyumardi Azra, 'Guru, Agama dan Negara', Republika , 20 September 2018, dari https: //republika.co.id, diakses 26 Agustus 2018 
membuktikan bahwa dalam tataran opini atau pemikiran radikal mereka dan mencari pembenaran atas tindakan radikal dengan masuk ke kelompok yang seide dengan mereka.

Seperti yang diungkapkan oleh seorang bekas narapidana teroris, Yudi Zulfahri yang mengatakan paham radikalisme atau terorisme berawal dari intoleransi. Yudi bahkan menyebut bibit-bibit radikalisme justru didapat dari pengajian di masjid-masjid kampus. Menurut Yudi, paham radikalisme ini ditularkan lewat mahasiswa atau pemuda karena mereka masih berjiwa kritis. Menurut dia, mahasiswa selalu ingin melakukan perlawanan sehingga mudah diiindroktinasi paham radikal. Sasaran utama gerakan radikal itu pemuda. ${ }^{37}$

Penelitian yang kedua meskipun baru pada tahap dukungan kepada sistem khilafah, sesungguhnya ini memberi tanda bahwa ada semacam keinginan untuk mengubah ideologi Pancasila. Hanya karena belum menemukan momen yang pas untuk mewujudkannya maka wujud aksi pemikiran ini belum nampak ke permukaan. Bukan tidak mungkin pendukung sistem khilafah akan bertambah karena sang pendukung berada di wilayah yang mudah untuk mencari pengikut. Figur guru sebagai sosok yang digugu dan ditiru akan banyak berpengaruh terhadap ideologi yang dipilih murid-muridnya.

Dari dua hasil penelitian yang dilakukan PPIM UIN Jakarta tersebut, jelas bahwa potensi berkembangnya radikalisme di lembaga pendidikan memang belum berada pada level mengkhawatirkan. Pepatah api dalam sekam pas kiranya disematkan pada penyebaran paham radikal di lembaga pendidikan saat ini. Kalau tak segera diatasi dalam waktu tak lama akan membakar konsep Islam rahmatan lil alamin ala Muslim Indonesia.

\section{Memutus Penyebaran Ideologi Radikal}

Upaya-upaya dalam memerangi gerakan radikal hingga terorisme dalam bentuk apapun, ada baiknya tidak dilakukan dengan cara-cara kekerasan, seperti yang dilakukan Amerika Serikat terhadap Afganistan. Hal ini karena kekerasan tersebut hanya akan menambah kekerasan jilid baru. Kejahatan kemanusiaan yang berjilid-jilid terhadap rakyat sipil yang tidak berdosa. Tidak bisa kita menumpas kemungkaran dengan kemungkaran.

Upaya melawan terorisme, harus bermula dari mencabut akar atau sumber masalah. Adapun akar atau sumber terpenting dari tindakan terorisme saat ini adalah menghapus ketidakadilan dan kepincangan dalam tatanan hubungan internasional. Perlu dialog yang intens

${ }^{37}$ Didit Haryadi, Cerita Eks Napi Teroris Soal Bibit Radikalisme di Kampus, Tempo.co, 6 September 2018 dari https://nasional.tempo.co, 
antara pihak-pihak yang bertikai agar benar-benar ditemukan solusi terbaik untuk mengakhiri konflik.

Indonesia beruntung memiliki banyak organisasi keagamaan yang berpaham Islam moderat. Islam yang rahmatan lil alamin. NU dan Muhammadiyah terbukti sepanjang sejarah mampu meredam percepatan arus penyebaran Islam radikal dengan konsep Islam washatiyyahnya. Dari hasil penelitian, NU yang dikenal dengan Islam tradisionalisnya dan Muhammadiyah yang dikenal dengan Islam modernisnya ternyata selama ini berfungsi sebagai penawar ideologi politik Islam. ${ }^{38}$

Azyumardi Azra menawarkan beberapa solusi alternatif yang bisa dilakukan dalam memutus mata rantai penyebaran ideologi radikal di Indonesia, ${ }^{39}$

1. Lembaga pendidikan perlu bekerja sama dengan orang tua, organisasi masyarakat berbasis agama guna meredam arus penyebaran paham radikal terhadap anak didiknya.

2. Guru dan dosen perlu diberikan diklat kebangsaan yang difasilitasi oleh pemerintah

3. Masjid benar-benar difungsikan sebagai wadah komunikasi seluruh jamaahnya, bukan hanya untuk kelompok tertentu. Masjid di wilayah sekitar kampus perlu mendapat perhatian serius dari pengelolanya agar bersikap tegas terhadap pihak-pihak yang ingin menggunakan masjid sebagai tempat penyebaran paham yang terbukti mengancam keutuhan NKRI.

4. Khusus di Perguruan Tinggi, perlu kiranya memasukkan kembali organisasi mahasiswa berbasis keagamaan seperti PMII, HMI agar ideologi Pancasila benar-benar terpatri dalam diri mahasiswa, sehingga ideologi di luar Pancasila tidak bisa berkembang.

5. Khusus para orang tua hendaknya bisa memonitor siapa guru agama anak-anaknya dan tahu dengan siapa anaknya bergaul sehingga dengan demikian bisa meminimalisir si anak terpapar ideologi radikal.

\section{Kesimpulan}

Kelompok Islam radikal dalam perkembangannya tidak muncul karena faktor agama. Ada banyak faktor yang menyebabkan seseorang bisa bertindak radikal. Hanya ketika mereka

\footnotetext{
${ }^{38}$ Data survei PPIM sepanjang 2001-2004, menunjukkan meskipun Indonesia dilanda fenomena gerakan salafi radikal, namun hasil survei membuktikan bahwa mayoritas Muslim masih setia dengan ideologi Islam yang moderat dan toleran. Lihat Jamhari dan Jajang Jahroni, Gerakan Salafi Radikal di Indonesia, Jakarta : RajaGrafindo Persada, 2004, xi

${ }^{39}$ Seperti disampaikan dalam ceramah pada mata kuliah Contemporary Islamic World, Program Doktor Pengkajian Islam Sekolah Pascasarjana Universitas Islam Negeri Syarif Hidayatullah Jakarta, Kamis, 11 Oktober 2018
} 
bersatu dalam bentuk kelompok, agama menjadi legitimasi untuk setiap aksi yang mereka lakukan.

Saat ini, para pengikut Islam radikal telah merambah pada kalangan terdidik. Sekolahsekolah maupun perguruan tinggi telah terpapar paham radikal meskipun belum sampai pada tahap yang mengkhawatirkan.

Usaha meredam penyebaran ideologi radikal tidak bisa dilakukan satu pihak. Penanganannya pun tidak hanya fokus pada si pelaku tindakan radikal atau teroris. Hal yang harus dipahami adalah ketika banyak terjadi tindakan radikalisme, pendekatan tidak hanya kepada ideologi namun juga pendekatan sosial dan budaya yang melatarbelakangi kenapa si pelaku bertindak radikal. 
Nurlaila

\section{Daftar Pustaka}

Azra, Azyumardi. 2016. Transformasi Politik Islam Radikalisme, Khilafatisme, dan Demokrasi. Jakarta : Paranamedia Group

Pluralitas. Jakarta: Rajagrafindo Persada

1996. Pergolakan Politik Islam: Dari Fundamentalisme, Modernisme Hingga Post-Modernisme. Jakarta: Paramadina.

Bakti, Agus Surya. 2014. Darurat Terorisme : Kebijakan Pencegahan, Perlindungan dan Deradikalisasi. Jakarta: Daulat Press

H. Purwanto, Wawan. 2007. Terorisme Undercover: Memberantas Terorisme hingga ke Akar-akarnya, Memungkinkah? Jakarta: CMB Press

Jamhari dan Jajang Jahroni. Gerakan Salafi Radikal di Indonesia, Jakarta : RajaGrafindo Persada, 2004,

Jurgensmeyer, Mark. 2003. Terorisme Para Pembela Agama. Yogyakarta: Terawang Press,

Madjid, Nurcholish. 1995. Pintu-Pintu Menuju Tuhan. Jakarta: Paramadina

Qadir, Zuly. 2014. Radikalisme Agama di Indonesia. Yogyakarta: Pustaka Pelajar

Hasan, Tolhah. " Islam dan Radikalisme Agama", pp.1-6. Diakses pada 14 September 2018 dari lp3.um.ac.id/downlot.php?file=80_01.

M. Bale, Jeffrey. "Denying the Link between Islamist Ideology and Jihadist Terrorism "Political Correctness"and the Undermining of Counterterrorism", pp. 5-27. Diakses pada 14 September 2018 dari https://about.jstor.org/terms//262970006

Carnegie, Paul J. "Countering the (Re-) Production of Militancy in Indonesia between Coercion and Persuasion": Perspectives on Terrorism, Vol. 9, No. 5 (October 2015), pp. 15-26 Diakses pada 14 September 2018 dari https://www.jstor.org/stable/26297431

Annamalai, Ganesan. “The Impact of Osama Bin Laden's death on the Landscape of Global Jihad : Counter Terrorist Trends and Analyses, Vol. 3, No. 8 (August 2011), pp. 10-

13. Diakses 24 September 2018 dari https://www.jstor.org/stable/26350999

Holtmann, Philipp. " 'Terrorism and Jihad Differences and Similarities' Perspectives on Terrorism," Vol. 8, No. 3 (June 2014), pp. 140-143. Diakses 24 September 2018 dari https://www.jstor.org/stable/26297185

Munip Abdul, "Menangkal Radikalisme di Sekolah. "Jurnal Pendidikan Islam Volume I Nomor 2 (2012 ): 159-181 dari https://www.researchgate.net

Azyumardi Azra, 'Guru, Agama dan Negara', Republika, 20 September 2018, dari https: 
//republika.co.id, diakses 26 Agustus 2018

Sa'dullah Affandy, Akar Sejarah dan Pola Radikalisme di Indonesia, 8 Juli 2016, dari www. nu.or.id diakses 23 September 2018

Riani Sanusi Putri, "LIPI Ungkap 4 Alasan Mengapa Radikalisme Berkembang di Indonesia”, Tempo.co, 20 Februari 2018 dari https://nasional.tempo.co/read/1062388,

Didit Haryadi, Cerita Eks Napi Teroris Soal Bibit Radikalisme di Kampus, Tempo.co, 6 September 2018 dari https://nasional.tempo.co,

Kapolda Bali Irjen Petrus R. Golose dalam seminar Ilmiah "Cara Menangani Terorisme" di STIK/PTIK, lihat https://news.detik.com, 20 Februari 2018, diakses 26 September 2018

Video program "Satu Meja” Kompas TV, 'Radikalisme Mencengkeram Kampus?', 4 Juni 2018 